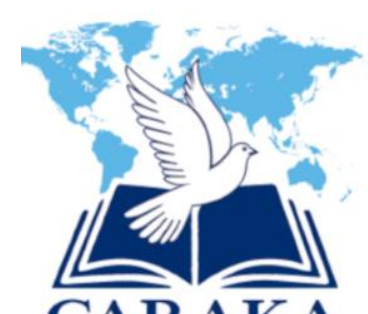
CARAKA

Vol 2, No 2 (November 2021)

Https://ojs.sttibc.ac.id/index.php/ibc

p-ISSN : 2722-1407

Doi: $10.46348 /$ car.v2i2.53

e-ISSN : 2722-1393

\begin{tabular}{|l|l|l|}
\hline Diserahkan: 19 April 2021 & Diterima: 7 November 2021 & Diterbitkan: 23 November 2021 \\
\hline
\end{tabular}

\title{
Tradisi Mupupantunu dan Korban Penebus Salah dalam Kitab Imamat
}

\author{
Alferdi \\ Institut Agama Kristen Negeri Toraja \\ alferdi35@gmail.com
}

\begin{abstract}
The purpose of this article is to examine one of the traditions in Seko and to be juxtaposed with victims of wrongdoing in Imamat. Traditions or customs within a certain community group that have a characteristic entity in their application. This article discusses a tradition that is quite unique, namely the Mupupantunu tradition in a part of Seko, namely in Kalamio. This tradition is a tradition of giving sanctions to members of society who violate wrong norms or mistakes. This tradition involves slaughtering an animal as a sacrifice and paying a predetermined fine. This tradition will be compared to the Fraud Sacrifice in the Book of Imamat. The traditions of Mupantunu and Sacrifice for the Falsehood are the same as animals in practice. This study uses descriptive qualitative methods with a literature study and interview approach, and shows that, the tradition that was born among the Seko (Mupantunu) people, especially the Kalamio area, had a large number of cults practiced by the Israelites of the Old Testament, namely the False Redeemers. The most striking similarity is that a watch has to offer an animal as a sacrifice, and there are also certain parts that are eaten by the adat leaders as implementers of the Mupupantunu tradition and the Priest as a sacrificial burner in the Book of Leviticus. Of these, there were also differences between victims, such as burning places or burnt offerings.
\end{abstract}

Keywords: Mupupantunu; False Redeemer; Book of Leviticus

\begin{abstract}
Abstrak
Tujuan dari penulisan artikel ini ialah akan mengkaji salah satu adat di Seko dan disandingkan dengan korban penebus salah dalam Imamat. Tradisi atau adat-istiadat dalam suatu golongan masyarakat tertentu mempunyai ciri khas tersendiri dalam penerapannya. Artikel ini membahas salah satu tradisi yang cukup unik yaitu tradisi Mupupantunu di salah satu daerah bagian Seko yaitu di Kalamio. Tradisi ini adalah tradisi pemberian sanksi kepada anggota masyarakat yang melanggar norma atau berbuat salah. Tradisi ini ditandai dengan penyembelihan hewan sebagai korban penebusnya dan juga membayar denda yang telah ditentukan. Tradisi ini akan coba dibandingkan dengan Korban Penebus Salah dalam Kitab Imamat. Tradisi Mupupantunu dan Korban Penebus Salah sama-sama mengorbankan hewan dalam prakteknya. Penelitian ini menggunakan metode kualitatif deskriptif dengan pendekatan studi kepustakaan dan wawancara, dan menunjukkan bahwa, tradisi yang lahir dari kalangan orang Seko (Mupupantunu) khususnya daerah Kalamio, memiliki sejumlah kesamaan dengan kultus yang dilaksanakan oleh orang Israel zaman Perjanjian Lama yaitu Korban Penebus Salah. Kesamaan yang paling menonjol ialah keduanya harus mempersembahkan hewan sebagai korban, dan juga ada bagian tertentu yang dimakan oleh Pemangku Adat sebagai pelaksana tradisi Mupupantunu dan Imam sebagai pembakar korban dalam Kitab Imamat.
\end{abstract}

283 | Copyright $@$ 2021, CARAKA, ISSN 2722-1407 (Cetak), 2722-1393 (Online) 
Terlepas dari semua itu, ada juga perbedaan di antara keduanya, seperti tempat pembakaran ataupun tempat memakan korban bakaran.

Kata Kunci: Mupupantunu; Korban Penebus Salah; Kitab Imamat

\section{PENDAHULUAN}

Manusia tidak ada yang sempurna merupakan ungkapan yang sering didengar dari orang-orang yang mencoba keluar dari kesalahan yang diperbuat. Tetapi nampaknya ungkapan ini tidak berlaku di sebuah daerah yang masih kental dengan adat-istiadat. Ketika perbuatan yang dilakukan tidak dapat ditolerir karena dianggap meresahkan dalam masyarakat, maka di saat itu pulalah ada sanksi yang harus diterima. Adanya suatu hukum adat yang berlaku dalam sebuah masyarakat tidak terlepas dari akal budi manusia yang mampu menciptakan kebudayaan dari hasil interaksinya dengan alam maupun manusia lainnya. ${ }^{1}$

Hukum adat pada dasarnya memang masih kental di daerah perkampungan, berbeda dengan perkotaan yang perlahan mulai hilang. Hukum adat yang diterapkan sebagai sanksi sosial nampaknya cukup efektif untuk membuat masyarakat jerah. Tetapi sangat disayangkan dengan adanya berbagai peraturan perundang-undangan yang diterapkan membuat hukum adat ini mengalami kemerosotan. Hukum adat tidak berjalan lagi sebagai mana mestinya dan bahkan hilang ditelan dengan kebiasaan-kebiasaan baru dan tentu dengan nilai yang baru pula. $^{2}$

Berbeda dengan Seko, sebuah daerah yang terletak di Kabupaten Luwu Utara Provinsi Sulawesi Selatan, sanksi sosial yang diterapkan dalam hukum adat masih dipegang erat sehingga kehidupan bermasyarakat juga menjadi tertib. ${ }^{3}$ Pemberlakuan hukum adat bukan berarti menghilangkan nilai-nilai Kristiani, tetapi justru hukum adat ini berjalan sesuai dengan nilai Kristiani. Penerapannya tidak lagi mengacu pada kepercayaan-kepercayaan yang dianut oleh nenek moyang orang Seko. Salah satu daerah di Seko yang masih menerapkan hukum adat adalah Kalamio yang merupakan salah satu dusun yang terdapat di Kecamatan Seko. Daerah ini merupakan daerah yang mayoritas diduduki oleh Kristen, sehingga kepercayaan animisme yang terkandung dalam hukum adatnya juga mengalami trasformasi.

Hukum adat yang berlaku dalam daerah ini dinamakan Mupupantunu yaitu pemberian sanksi yang juga diikuti dengan pembayaran denda. Hukum adat memiliki sejumlah kesamaan dengan korban penebus salah dalam kitab Imamat, di mana keduanya menuntut korban yang

\footnotetext{
${ }^{1}$ Herianto and Winarno, Ilmu Sosial Dan Budaya Dasar (Jakarta: PT Bumi Aksara, 2019), 21.

${ }^{2}$ Lastuti Abubakar, "Revitalisasi Hukum Adat Sebagai Sumber Hukum Dalam Membangun Sistem Hukum Di Indonesia,” Jursnal Dinamika Hukum Vol. 13, no. 2 (2013): 319-331.

3 Yoel Brian Palari, "Pandangan Perjanjian Lama Terhadap Adat Masseroi Tondok Di Seko," OSF Preprints.
} 
berupa hewan sebagai substansi pelaksanaannya. Tulisan ini akan mengkaji hukum adat atau tradisi Mupupantunu yang dibandingkan dengan korban penebus salah dalam kitab Imamat. Dari segi penerapannya, tradisi ini cukup efektif dalam mengubah sistem kehidupan masyarakat sehingga cenderung hidup lebih baik.

Berbalik atau bertobat pada Tuhan memang adalah sesuatu yang dituntut dalam kehidupan manusia. Tradisi Мuрираntunu hadir menjawab hal tersebut dengan menuntut pengakuan yang sungguh dari orang-orang yang melanggar hukum adat. Pengakuan yang mereka lakukan dan diikuti dengan pemberian sanksi mengubah sistem kehidupan ke arah yang lebih baik. Bukan hanya kehidupan bermasyarakat yang menjadi tertib, tetapi spiritual seseorang juga bertumbuh, diperlihatkan dengan pertobatan yang dilakukan setelah menerima sanksi adat. Tulisan ini bertujuan untuk mengkaji sistem tradisi Mupupantunu dan disandingkan korban penebus salah dalam kitab Imamat. Мирираntunu adalah sistem penghapusan kesalahan yang diawali dengan pengakuan, dan diakhiri dengan penyembelihan hewan sebagai korban dan juga membayar denda berupa uang. Yang ingin dicapai dalam tulisan ini ialah bagaimana melihat tradisi ini dari segi upacara korban penebus salah dalam kitab Imamat, dan apakah masih relevan dengan nilai-nilai Kristiani.

\section{METODE PENELITIAN}

Dalam mengkaji artikel ini, penulis menggunakan metode kualitatif deskriptif yang merupakan suatu metode yang menjelaskan masalah/objek secara rinci, ${ }^{4}$ dengan metode pengumpulan data dilakukan dengan studi kepustakaan. Penulis akan memanfaatkan berbagai sumber seperti, jurnal, buku serta artikel-artikel online lainnya. ${ }^{5}$ Selain itu, penulis juga akan menggunakan metode wawancara kepada tokoh-tokoh adat untuk memperoleh informasi seputar tradisi Mupupantunu. Metode penelitian survey dengan wawancara, merujuk pada metode yang dipopulerkan oleh Morrisan. ${ }^{6}$

Ketiga metode yang penulis pilih semuanya digunakan dalam memperoleh berbagai informasi sekaitan dengan tradisi Мupupantunu dan juga korban penebus salah dalam kitab Imamat. Metode kualitatif deskriftif dengan menggunakan pendekatan studi kepustakaan adalah metode yang penulis gunakan dengan memanfaatkan berbagai sumber, seperti jurnal maupun buku-buku. Tentunya buku/jurnal yang digunakan adalah yang berkaitan dengan apa yang penulis kaji (tradisi Mupupantunu dan korban penebus salah). Kemudian metode wawancara adalah teknik pengumpulan data yang penulis gunakan dengan cara melakukan wawancara dengan tokoh-tokoh kemasyarakatan yang paham dengan tradisi Mupupantunu.

${ }^{4}$ Bagong Suyanto, Metode Penelitian Sosial: Berbagai Alternatif Pendekatan (Jakarta: Prenada Media Group, 2015), 14.

${ }^{5}$ Kartini Kartono, Pengantar Metodologi Research Sosial (Bandung: Alumni Bandung, 1980), 78.

${ }^{6}$ M. A. Morrisan, Metode Penelitian Survei (Jakarta: Prenada Media Group, 2012), 26. 
Metode survey adalah metode dengan cara mengamati langsung proses pelaksaanaan tradisi Mupupantunu sehingga data-data yang penulis kumpulkan dalam metode wawancara lebih akurat lagi.

\section{HASIL DAN PEMBAHASAN}

\section{Tradisi Mupupantunu}

Dalam suatu golongan masyarakat tertentu, tentunya memiliki hukum tak tertulis yang selalu dipertahankan dalam pergaulan hidup, untuk menjadi pedoman dalam menerapkan kehidupan yang berkeadilan. ${ }^{7}$ Begitu juga dengan Kalamio salah satu daerah yang terletak di Seko, mempunyai hukum adat untuk mengatur kehidupan masyarakat. Kalamio merupakan suatu dusun yang terletak di Desa Marante, Kecamatan Seko, Kabupaten Luwu Utara, Sulawesi Selatan. Letaknya yang sangat jauh dari perkotaan membuat daerah ini jarang diketahui oleh banyak orang, dan bahkan daerah ini adalah salah satu daerah yang terisolir dan jauh dari pembangunan. Istilah adat yang sering dilaksankan untuk memberikan sanksi terhadap yang melanggar, dikenal dengan nama Мирираntunи. Pelanggaran terhadap setiap ketentuan yang berlaku dalam masyarakat akan mendapatkan sanksi ini. Namun perlu dipahami bahwa tidak semua kesalahan mendapatkan sanksi Mupupantunu, hanya ada beberapa yang dianggap mengotori nama baik kampung. Pelanggaran masyarakat yang dikenai hukum adat Mирираntunu, di antaranya yaitu Nipakaleang (hamil di luar nikah), Mamunau (mencuri), Mupana'i (memukul orang lain), Mampunaha bahine/muanena tau (menyukai istri/suami orang lain) dan Mupakaleang (memperkosa). Dari semua pelanggaran tidak bisa lagi ditolerir, dan harus mendapatkan sanksi (Mupupantunu). ${ }^{8}$

Hampir semua daerah di Kecamatan Seko menerapkan hukum adat ini, hanya saja nama bahkan tata cara pelaksanaannya berbeda-beda tergantung dari bahasa yang digunakan. Ketika melihat lebih jauh, nampaknya ritus pencurahan korban tidak asing lagi bagi sebagian orang, karena sangat umum. ${ }^{9}$ pada awalnya tradisi Мupupantunu sangat bertentangan dengan iman Kristen. Hal ini disebabkan karena penyembelian hewan dalam tradisi ini dianggap bisa menghapuskan dosa bagi yang dikenai sanksi. Oleh karena pemahaman itulah sehingga anggapan bahwa semakin besar hewan yang dikorbankan maka dosa yang dilakukan juga akan cepat diampuni juga menjadi salah satu bagian penting dalam tradisi ini. Karena persoalan inilah banyak anggota masyarakat yang merasa terbebani karena hewan yang dikorbankan tidak disesuaikan pelanggaran yang dilakukan. ${ }^{10}$

\footnotetext{
${ }^{7}$ R. Soepomo, Kedudukan Hukum Adat Di Kemudian Hari (Jakarta: Pustaka Rakyat, 1952), 30.

${ }^{8}$ Ruben Lamara. Tradisi Mupupantunu. Wawancara oleh Alferdi. 8 Januari 2021

${ }^{9}$ Patrecia Hutagalung, "Pemuridan Sebagau Mandat Misi Menurut Matius 28:18-20," Pengarah: Jurnal Teologi Kristen Vol. 2, no. 1 (2020): 73.

${ }^{10}$ Ruben Lamara. Tradisi Mupupantunu. Wawancara oleh Alferdi. 8 Januari 2021. 
Seiring dengan masuknya Kekristenan di Seko maka perlahan kepercayaankepercayaan itu mulai dihilangkan. Hewan yang disembelih dalam tradisi Mupupantunu sudah disesuaikan dengan jenis pelanggarannya atau pun strata sosialnya dan bukan lagi mengarah pada korban penghapus dosa kepada roh nenek moyang yang disebut Diata (Dewa), tetapi lebih kepada sanksi sosial agar masyarakat bisa tertib (jerah) atau lebih tepatnya bahwa penyembelian hewan itu merujuk pada korban penghapus salah. ${ }^{11} \mathrm{Jadi}$, semakin besar jenis pelanggaran yang dilakukan maka akan semakin besar pula hewan yang disembelih untuk korban penghapus salah. Sama halnya dengan tradisi Massuru' di Toraja, tradisi ini juga mengandung pengakuan, pertobatan dan pengampunan salah. ${ }^{12}$

Tata cara pelaksanaan tradisi ini bergantung pada daerah di mana dilaksanakan. Semua daerah yang termasuk ke dalam bagian Kecamatan Seko memiliki tata cara yang berbeda-beda dalam melaksanakannya. Daerah Kalamio secara khusus mempunyai cara yang berbeda dengan daerah lainnya sekaitan dengan tata cara pelaksanaannya. Ketika ada anggota masyarakat yang melanggar (misalnya berzinah), maka pada saat itu pemangku Adat atau yang lebih akrab disebut Tobara' yaitu pemimpin dalam kampung, ${ }^{13}$ akan mengumpulkan tokoh masyarakat lainnya seperti tokoh pemuda dan tokoh agama untuk membicarakan persoalan tersebut. Pokok utama yang dibicarakan ialah masalah hewan yang akan disembelih dan juga denda yang biasa berupa uang. Yang melanggar ketentuan yang berlaku akan dihadirkan dalam pembicaraan ini untuk bisa dimintai keterangan dan hal yang paling dituntut ialah pengakuan. Ketika pelanggaran dan hewan yang akan disembelih sudah sesuai, maka pembicaraan pertama dianggap selesai, dan tinggal menentukan pertemuan selanjutnya untuk menyembelih hewan tersebut. ${ }^{14}$

Ketika tiba saat yang telah ditentukan, maka hewan kemudian diserahkan kepada Tobara untuk selanjutnya disembelih, dan bagian-bagian tertentu dimakan bersama oleh tokoh-tokoh masyarakat yang hadir. Denda yang biasa berupa uang murni menjadi milik Tobara' kampung. Pada saat itu pula kesalahan yang dilakukan dihapuskan. Dari penjelasan tersebut dapat disimpulkan bahwa Мuрupantunu merupakan proses pengakuan kesalahan yang telah melanggar adat, yang ditandai dengan mengorbankan hewan (disembelih) kemudian dimakan secara bersama-sama oleh tokoh-tokoh masyarakat yang hadir. Hal ini juga dilakukan oleh masyarakat karena seseorang yang melanggar hukum adat dianggap telah mengotori nama baik kampung, dan hanya dengan jalan ini kesalahannya bisa diampuni.

11 Zakaria J. Ngelow and Marta Kumala, Malea Allo Mepantu' Borron Bulan Meampangngi: Masyarakat Seko Pada Masa DI/TII (1951-1965) (Makassar: Yayasan Ina Seko, 2008), 210-269.

${ }^{12}$ Frans Paillin Rumbi, "Tradisi Massuru' Dan Pertobatan Dalam Injil Sinoptik," BIA: Jurnal Teologi dan Pendidikan Kristen Kontekstual Vol. 1, no. 1 (2018): 26-38.

${ }^{13}$ Ngelow and Kumala, Malea Allo Mepantu’Borron Bulan Meampangngi: Masyarakat Seko Pada Masa DI/TII (1951-1965), 4.

${ }^{14}$ Hendrik. Teknik Pelaksanaan Tradisi Mupupantunu. Wawancara oleh Alferdi. 13 Januari 2021 287 | Copyright@ 2021, CARAKA, ISSN 2722-1407 (Cetak), 2722-1393 (Online) 
Dalam kaitannya dengan Мupupantunu yang masih dilaksanakan hingga saat ini, orang yang diberi sanksi harus mengakui semua kesalahannya di depan semua tokoh-tokoh kemasyarakatan yang hadir. Kehadiran tokoh agama seperti majelis gereja ataupun pendeta dalam pembicaraan ini, memberikan indikasi bahwa pelanggaran yang dilakukan bukan hanya menyangkut pelanggaran adat tetapi lebih kepada hubungan manusia dengan Tuhan. Artinya bahwa setiap pelanggaran yang dilakukan yang juga tidak bisa ditolerir oleh adat merupakan perbuatan dosa sehingga memerlukan suatu pengakuan sebagai bukti pertobatan. Hal inilah sehingga dianggap perlu menghadirkan tokoh agama untuk memberi pemahaman kepada pelanggar adat, sehingga tradisi yang dilakukan bukan sekedar pengakuan kesalahan karena adat, tetapi pertobatan yang sungguh dari pelanggar. ${ }^{15}$

Jika dipandang secara Alkitabiah, tradisi Mupupantunu sangatlah efektif karena bukan hanya menuntut pengakuan kesalahan, tetapi pertobatan yang disaksikan oleh tokoh agama lebih diutamakan. Jadi sebenarnya yang terjadi ialah bagaimana membuat orang yang telah melanggar adat bisa bertobat dari dosanya dengan diberi sanksi adat, dan hewan yang disembelih bukan penghapus dosa, hanya sebagai bukti pengakuan kesalahan. ${ }^{16}$ Hewan yang dikorbankan dalam tradisi Mupupantunu bukan penghapus dosa karena masyarakat Seko khususnya agama Kristen memahami dan percaya dengan sungguh bahwa, hanya pengorbanan Yesus dosa manusia bisa dihapuskan seperti yang diungkapkan oleh Jonar bahwa pembebasan kekal adalah dari Imam Besar yaitu Yesus Kristus. ${ }^{17}$ Yesuslah yang menjadi puncak atau klimaks. ${ }^{18}$

\section{Korban Penebus Salah, Perspektif Kitab Imamat}

Berbicara mengenai kurban dalam Perjanjian Lama, tampaknya menjadi hal asing bagi sebagian orang. Berbagai pengalaman dalam kehidupan yang berkaitan erat dengan binatang seperti membunuh, memotong-motong, memercikan darah, membakar dan membuang bangkai binatang dan burung-burung, sangat sulit dipahami jika dipandang dari perspektif orang Israel kuno. Bahkan anggapan-anggapan mulai muncul bahwa bahan-bahan yang berkaitan dengan kurban ini tidaklah penting. Hal ini disebabkan kerena, pertama bahwa sebagai orang Kristen kita percaya bahwa kematian Yesus telah menghapuskan kebutuhan akan sistem kurban seperti yang ada dalam Perjanjian Lama. Kedua, bahwa ada juga yang beranggapan bahwa kurban dalam Perjanjian Lama bukanlah bagian utama dalam agama. ${ }^{19}$

\footnotetext{
${ }^{15}$ Suleman Murni. Makna Teologis Tradisi Mupupantunu. Wawancara Oleh Alferdi. 15 Januari 2021

16 Ngelow and Kumala, Malea Allo Mepantu' Borron Bulan Meampangngi: Masyarakat Seko Pada Masa DI/TII (1951-1965).

${ }^{17}$ Jonar S., Soteriologi: Doktrin Keselamatan (Yogyakarta: ANDI, 2019), 205.

18 Iman Nuel Zai and Thuan Ong, "Memahami Konsep Penebusan Dalam Hukum Taurat Dan Penggenapannya Dalam Diri Yesus Kristus," Jurnal Teologi Pondok Daud Vol. 6, no. 1 (2020): 1-7.

${ }^{19}$ John Rogerson, Studi Perjanjian Lama Bagi Pemula (Jakarta: BPK Gunung Mulia, 2006), 69. 
Kitab Imamat merupakan kitab yang berisi kultus, yang menurut ahli berasal dari sumber P, meskipun di dalamnya masih ada unsur-unsur kuno. Namun, untuk memahami kultus yang berasal dari bangsa Israel ini, maka dipandang perlu untuk membandingkannya dengan kultus-kultus dengan bangsa lain (kafir) di sekitar Israel. Pada umumnya kultus kafir itu dihubungkan dengan penciptaan; manusia dijadikan untuk melayani dan memelihara dewadewa dalam kultus, supaya dewa-dewa memelihara kosmos. Dalam Perjanjian Lama kultus dihubungkan dengan konsepsi persekutuan, perjanjian antara Allah dengan bangsa Israel; maksud kultus ini ialah untuk memelihara relasi antara Yahweh dengan umat-Nya. ${ }^{20}$

Kitab Imamat memberitahukan bagaimana umat yang berdosa dapat mendekati Allah yang kudus dan bagaimana mereka dapat hidup kudus. Karena hal itulah Allah menentukan serangkaian korban persembahan yang dilaksanakan oleh Imam besar, dan jika hal tersebut dilanggar maka akan mendapatkan hukuman yang berat. ${ }^{21}$. Jadi, setiap kultus yang terdapat dalam kitab Imamat hanya berusaha menjaga hubungan antara manusia dengan Allah. Ini menekankan bahwa Allah pada dasarnya kudus sehingga untuk bisa membangun relasi dengan Allah maka manusia juga harus kudus. ${ }^{22}$ Korban atau bahasa Ibrani kipper adalah suatu kultus dalam PL yang berlaku bagi orang Israel

Salah satu kultus yang terdapat dalam kitab Imamat ialah Korban Penebus Salah. Dari segi cara mempersembahkan korban, kultus ini hampir sama dengan korban penghapus dosa, dan sangat susah untuk membedakan maksud atau arti dari kedua kultus ini. Denis Green menjelaskan bahwa kemungkinan korban penghapus dosa dipakai berhubungan dengan dosa terhadap Allah, sedangkan korban penebus salah dipakai berhubungan dengan dosa terhadap sesama manusia karena didalamnya menuntut pembayaran ganti rugi. ${ }^{23}$ Perbuatan dosa terhadap sesama manusia lebih mencolok dalam asam, dan perbuatan dosa terhadap Allah dalam hatta't. ${ }^{24} \mathrm{Hal}$ ini diperkuat oleh W.S Lasor, bahwa korban penebus salah menuntut ganti rugi kepada orang yang dirugikan oleh dosa tersebut. ${ }^{25}$ Korban Penghapus Salah adalah upacara yang muncul karena rasa bersalah, dan terbawa dalam kondisi bersalah terutama dalam konteks hukuman. ${ }^{26}$ Sesuai dengan judulnya "Korban Penghapus Dosa", maka pada dasarnya upacara ini membutuhkan sebuah korban berupa hewan. Binatang yang dikorbankan bisa berupa kambing, domba, atau bahkan seekor burung. Dengan upacara seperti itu maka kedua bela pihak mengikatkan diri satu dengan yang lain, dan sekaligus mengikatkan diri

20 Ani Teguh Purwanto, "Arti Korban Menurut Kitab Imamat," Jurnal Teologi dan Pelayanan KERUSSO Vol. 2, no. 2 (2017): 8-14.

${ }^{21}$ Herbert Wolf, Pengenalan Pentateukh (Malang: Gandum Mas, 1998), 219.

22 Ibid., 220.

${ }^{23}$ Denis Green, Pengenalan Perjanjian Lama (Malang: Gandum Mas, 2012), 58.

${ }^{24}$ William Dyrnes, Tema-Tema Dalam Teologi Perjanjian Lama (Malang: Gandum Mas, 2013), 136.

${ }^{25}$ W. S. Lasor, D. A. Hubbard, and F. W. Bush, Pengantar Perjanjian Lama 1 (Jakarta: BPK Gunung Mulia, 2019), 217.

${ }^{26}$ F. L. Baker, Sejarah Kerajaan Allah 1 (Jakarta: BPK Gunung Mulia, 2007), 368. 
mereka sendiri bahkan jika melanggar janji yang diucapkan mereka akan mengalami nasib seperti binatang korban itu. Namun dalam serangkaian upacara korban ini perlu diingat bahwa hanya satu pihak saja yang mengambil bagian di dalamnya. ${ }^{27}$

Imamat dengan jelas menguraikan tata cara dalam melaksanakan Korban Penebus Salah. Dalam terjemahan BIMK judul perikop ini lebih dikenal dengan korban ganti rugi dari kata Ibrani yang mempunyai arti dasar kesalahan. Korban ini dipersembahkan oleh orang yang berbuat salah terhadap Allah dan juga sesamanya. ${ }^{28}$ Korban ganti rugi ini lebih kepada dosa yang tidak disengaja dan berkaitan dengan kerugian terhadap sesamanya dan dilaksanakan dalam rangka ganti rugi. ${ }^{29}$ Tetapi intinya ialah untuk menebus dosa dan kesalahan. ${ }^{30}$ Meskipun sangat sulit mengidentifikasi apa yang penulis Kitab Imamat maksud dengan tidak sengaja berbuat dosa. Robert menjelaskan bahwa ungkapan ini berarti orang yang bersalah adalah sama seperti anak-anak panah yang tidak mendapat sasarannya. ${ }^{31}$ Artinya bahwa dosa ini murni bukan sesuatu yang disengaja, tetapi kerena keterbatasan manusia dalam mengantisipasi diri. Korban dalam upacara ini adalah hewan yang tidak bercacat, dan seperti biasanya dalam kalangan Israel korban ini harus diserahkan kepada Imam sebagai pelaksana dalam membakar korban. Petunjuk mengenai korban penebus salah terdiri dari tiga bagian, yaitu: tentang dosa di bidang ritual yang merugikan imam, dosa yang tidak diketahui dan dosa orang yang berusaha mengambil dengan tidak sopan barang orang lain. ${ }^{32}$

Yang menarik ialah di mana ada bagian-bagian tertentu yang dimakan oleh laki-laki di antara para imam (Imamat 7:6). Namun perlu dipahami bahwa terjemahan mengenai laki-laki di antara para imam tidak boleh menimbulkan kesan bahwa di antara imam itu ada kaum perempuan. Sehingga untuk menegaskan hal tersebut, terjemahan BIMK menyatakan, "setiap orang laki-laki dalam keluarga imam-imam, bukan hanya para imam saja. Selain bagian berlebih dari daging korban tersebut imam juga menerima bagiannya dari persembahanpersembahan lainnya. ${ }^{33}$ Hal yang paling umum yang menjadi korban penebus salah ialah kambing jantan ataupun burung merpati atau burung tekukur, ${ }^{34}$ yang dibuat agar orang miskin pun dapat mempersembahkan sesuatu sesuai dengan kemampuannya, ${ }^{35}$ dan ditambah dengan

${ }^{27}$ S. Wismoady Wahono, Di Sini Kutemukan: Petunjuk Mempelajari Dan Mengajarkan Alkitab (Jakarta: BPK Gunung Mulia, 2009), 98.

${ }^{28}$ Rene Peter-Contesse and John Ellington, Pedoman Penafsiran Alkitab: Kitab Imamat (Jakarta: Lembaga Alkitab Indonesia, 2020), 82.

29 Emanuel Gerrit Singgih, Dua Konteks: Tafsir-Tafsir Perjanjian Lama Sebagai Respon Atas Perjalanan Reformasi Di Indonesia (Jakarta: BPK Gunung Mulia, 2009), 57.

${ }^{30}$ M. Mashem, Misteri Darah Dan Penebusan Dosa (Jakarta: PT Mizan Pustaka, 2005), 110.

${ }^{31}$ Robert M. Paterson, Tafsiran Alkitab: Kitab Imamat (Jakarta: BPK Gunung Mulia, 2011), 82.

32 Ibid., 84-85.

${ }^{33}$ Peter-Contesse and Ellington, Pedoman Penafsiran Alkitab: Kitab Imamat, 110-111.

${ }^{34}$ Yap Wei Fong et al., Handbook to the Bible: Pedoman Lengkap Pendalaman Alkitab (Bandung: Kalam Hidup, 2014), 194.

${ }^{35}$ Dyrnes, Tema-Tema Dalam Teologi Perjanjian Lama, 136. 
denda untuk para imam. Sehingga sebagaimana yang diungkapkan oleh Margaret bahwa kemungkinan besar para imam menerima reseki dari korban penebus salah, dan bukan untuk perbaikan Bait Allah. ${ }^{36}$ Proses di mana para imam memakan bagian yang telah ditentukan juga harus disajikan dengan kudus dan di tempat kudus. ${ }^{37}$

\section{Persamaan dan Perbedaan Tradisi Mupupantunu dan Korban Penebus Salah}

Tradisi Mupupantunu dan Korban Penebus Salah memiliki sejumlah kesamaan dan perbedaan. Persamaan paling signifikan dari keduanya ialah sama-sama menuntut korban berupa hewan. Hewan yang disembelih dalam kedua korban ini adalah hewan yang tidak bercacat, dan disesuaikan dengan strata sosial yang berlaku dalam masyarakat. Pengakuan yang sungguh dibutuhkan dalam kedua upacara ini sehingga hubungan dengan Allah bisa dipulihkan kembali. Dalam melaksanakan tradisi ini hewan yang dikorbankan akan dimakan oleh Tobara dan tokoh-tokoh agama lainnya dalam tradisi Mupupantunu dan Imam dalam Korban Penebus Salah. Perbedaannya ialah jika dalam Korban Penebus Salah ada yang dipersebahkan sebagai korban api-apian bagi Tuhan, dalam tradisi Mupupantunu sebagian diserahkan kepada Tobara' dan sisahnya itulah yang dimakan bersama.

Keduanya juga mengenal sistem pembayaran denda yang murni milik Tobara dan Imam. Keduanya juga memiliki perspektif yang sama bahwa denda itu bukan untuk kepentingan lain tetapi menjadi upah yang diterima. Bagi Imam upah yang diterima ini bukan untuk pembangunan Bait Suci. Proses pelaksanaan korban diserahkan kepada yang dianggap relevan melaksanakannya seperti Tobara dalam tradisi Mupupantunu dan Imam dalam korban penebus salah. Kedua tokoh inilah yang bisa menyembelih hewan yang dijadikan korban penghapus salah. Pelaksanaan korban penghapus salah dilatarbelakangi oleh kesalahan yang tidak disengaja dilakukan, dan dapat merugikan orang lain. Berbeda dalam tradisi Mupupantunu, yang dilakukan karena adanya sebuah kesalahan yang dilakukan perseorangan dan itu murni adalah sesuatu yang disengaja (mencuri, memukul dan lain sebagainya).

Baik Mupupantu dan Korban Penebus Salah tidak dilakukan secara sepihak oleh Tobara' maupun Imam, tetapi betul-betul diputuskan sesuai dengan kesalahan atau pun strata sosial. Mupupantunu hanya akan memberikan sanksi sosial berupa ayam sebagai korban, dan burung merpati dalam korban penebus salah bagi mereka yang berada di golongan masyarakat terendah atau tergolong miskin. Unsur pertobatan yang sungguh kepada Allah juga hal utama yang dituntut keduanya, tetapi bukan berarti bahwa korban itulah yang mampu menghapus dosa, hanya sebagai simbol bahwa kesalahannya telah dihapuskan. Tradisi Mupupantunu juga

${ }^{36}$ Margaret Barker, Pintu Gerbang Sorga: Sejarah Dan Simbol Bait Allah Di Yerusalem (Jakarta: BPK Gunung Mulia, 2004), 41.

37 Abraham Park, Imam Besar Kekal Yang Dijanjikan Dengan Sumpah (Jakarta: Yayasan Damai Sejahtera Utama, 2016).

291 | Copyright $\odot$ 2021, CARAKA, ISSN 2722-1407 (Cetak), 2722-1393 (Online) 
menuntut hewan yang tidak bercacat, tetapi tempat tidak harus kudus seperti dalam upacara penebus salah.

\section{KESIMPULAN}

Tradisi Mupupantunu adalah sebuah tradisi yang dilakukan untuk menghapuskan kesalahan bagi yang melanggar adat. Tradisi ini ditandai dengan penyembelihan hewan dan pembayaran sejumlah hewan yang telah ditentukan oleh Tobara' dan tokoh masyarakat lainnya. Tradisi ini sama dengan Korban Penebus Salah dalam kitab Imamat yang juga menuntut hewan sebagai korban. Kesalahan yang disengaja merupakan latar belakang pelaksanaan tradisi ini, dan berbeda dengan korban penebus salah yang adalah kesalahan yang tidak disengaja. Bagian hewan tertentu dalam korban Mupupantunu menjadi milik Tobara' dan dalam korban penebus salah dibakar sebagai korban api-apian untuk Tuhan, sisanya sama dengan tradisi Mupupantunu yaitu dimakan secara bersama-sama.

Baik Mupupantunu atau pun korban penebus salah sama membutuhkan pengakuan sebagai dasar pelaksanaannya. Pengakuan dari umat Israel yang merasa bersalah dan mengakuinya merupakan hal utama yang dituntut untuk pelaksanaannya, begitu juga dalam tradisi Mupupantunu di mana pelanggar adat akan duduk bersama dengan Tobara' dan tokohtokoh masyarakat lainnya mendengarkan pengakukan untuk bisa ditindaklanjuti. Namun perlu diingat bahwa korban dari keduanya bukanlah sesuatu yang mampu menghapuskan dosa, karena hanya Yesus yang mampu melakukan hal tersebut dengan mengorbankan dirinya di atas kayu salib.

\section{DAFTAR PUSTAKA}

Abubakar, Lastuti. "Revitalisasi Hukum Adat Sebagai Sumber Hukum Dalam Membangun Sistem Hukum Di Indonesia.” Jurnal Dinamika Hukum Vol. 13, no. 2 (2013): 319331.

Baker, F. L. Sejarah Kerajaan Allah 1. Jakarta: BPK Gunung Mulia, 2007.

Barker, Margaret. Pintu Gerbang Sorga: Sejarah Dan Simbol Bait Allah Di Yerusalem. Jakarta: BPK Gunung Mulia, 2004.

Dyrnes, William. Tema-Tema Dalam Teologi Perjanjian Lama. Malang: Gandum Mas, 2013. Fong, Yap Wei, Agnes Maria Layantara, Ester Santosa, Tan Giok Lie, and Fenny Veronica. Handbook to the Bible: Pedoman Lengkap Pendalaman Alkitab. Bandung: Kalam Hidup, 2014.

Green, Denis. Pengenalan Perjanjian Lama. Malang: Gandum Mas, 2012.

Herianto, and Winarno. Ilmu Sosial Dan Budaya Dasar. Jakarta: PT Bumi Aksara, 2019. Hutagalung, Patrecia. "Pemuridan Sebagau Mandat Misi Menurut Matius 28:18-20." Pengarah: Jurnal Teologi Kristen Vol. 2, no. 1 (2020): 73.

Kartono, Kartini. Pengantar Metodologi Research Sosial. Bandung: Alumni Bandung, 1980. Lasor, W. S., D. A. Hubbard, and F. W. Bush. Pengantar Perjanjian Lama 1. Jakarta: BPK Gunung Mulia, 2019.

Mashem, M. Misteri Darah Dan Penebusan Dosa. Jakarta: PT Mizan Pustaka, 2005.

Morrisan, M. A. Metode Penelitian Survei. Jakarta: Prenada Media Group, 2012. 
Ngelow, Zakaria J., and Marta Kumala. Malea Allo Mepantu'Borron Bulan Meampangngi: Masyarakat Seko Pada Masa DI/TII (1951-1965). Makassar: Yayasan Ina Seko, 2008.

Palari, Yoel Brian. "Pandangan Perjanjian Lama Terhadap Adat Masseroi Tondok Di Seko." OSF Preprints.

Park, Abraham. Imam Besar Kekal Yang Dijanjikan Dengan Sumpah. Jakarta: Yayasan Damai Sejahtera Utama, 2016.

Paterson, Robert M. Tafsiran Alkitab: Kitab Imamat. Jakarta: BPK Gunung Mulia, 2011.

Peter-Contesse, Rene, and John Ellington. Pedoman Penafsiran Alkitab: Kitab Imamat. Jakarta: Lembaga Alkitab Indonesia, 2020.

Purwanto, Ani Teguh. “Arti Korban Menurut Kitab Imamat.” Jurnal Teologi dan Pelayanan KERUSSO Vol. 2, no. 2 (2017): 8-14.

Rogerson, John. Studi Perjanjian Lama Bagi Pemula. Jakarta: BPK Gunung Mulia, 2006.

Rumbi, Frans Paillin. "Tradisi Massuru' Dan Pertobatan Dalam Injil Sinoptik." BIA: Jurnal Teologi dan Pendidikan Kristen Kontekstual Vol. 1, no. 1 (2018): 26-38.

S., Jonar. Soteriologi: Doktrin Keselamatan. Yogyakarta: ANDI, 2019.

Singgih, Emanuel Gerrit. Dua Konteks: Tafsir-Tafsir Perjanjian Lama Sebagai Respon Atas Perjalanan Reformasi Di Indonesia. Jakarta: BPK Gunung Mulia, 2009.

Soepomo, R. Kedudukan Hukum Adat Di Kemudian Hari. Jakarta: Pustaka Rakyat, 1952.

Suyanto, Bagong. Metode Penelitian Sosial: Berbagai Alternatif Pendekatan. Jakarta: Prenada Media Group, 2015.

Wahono, S. Wismoady. Di Sini Kutemukan: Petunjuk Mempelajari Dan Mengajarkan Alkitab. Jakarta: BPK Gunung Mulia, 2009.

Wolf, Herbert. Pengenalan Pentateukh. Malang: Gandum Mas, 1998.

Zai, Iman Nuel, and Thuan Ong. "Memahami Konsep Penebusan Dalam Hukum Taurat Dan Penggenapannya Dalam Diri Yesus Kristus." Jurnal Teologi Pondok Daud Vol. 6, no. 1 (2020): 1-7. 